\title{
MRSA 敗血症をきたしたペースメーカー感染の 1 治験例
}

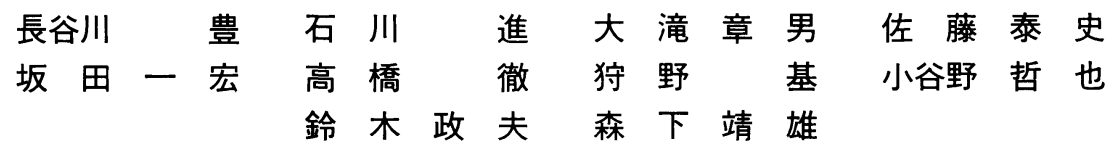

\begin{abstract}
患者は 78 歳, 男性で, ペースメーカーの入れ換え術後, 遺残電極の感染による皮下膿瘍から敗血症と なった，体外循環を用いて心停止下に右房を切開し，疣贅を伴う感染リード 3 本を摘出した。細菌培 養ではメチシリンーセフェム耐性黄色ブドウ球菌（MRSA)が検出された。術後はバンコマイシンなど の抗生物質投与を行い治瘉せしめた. ペースメーカー感染, とくに MRSA による敗血症症例では, 心 内膜病変の確認・感染巣の完全摘除のため体外循環を用いて直視下にリードを抜去することが望まし い. 日心外会誌 24 巻 5 号 : 347-350(1995)
\end{abstract}

Keywords：ペースメーカー感染, 敗血症, MRSA, 開心術

\section{Total Removal of a Contaminated Pacemaker under Cardiopulmonary Bypass in a Case of MRSA Septicemia}

Yutaka Hasegawa, Susumu Ishikawa, Akio Otaki, Yasushi Sato, Kazuhiro Sakata, Toru Takahashi, Motoi Kano, Tetsuya Koyano, Masao Suzuki and Yasuo Morishita (Second Department of Surgery, Gunma University School of Medicine, Maebashi, Japan)

A 78-year-old man underwent successful removal of a contaminated pacemaker in a case of methicillin-resistant Staphylococcus aureus (MRSA) septicemia. Septicemia was due to a subcutaneous abscess at the site of old cut electrodes. Following debridement of the infected pacemaker pocket, residual leads and the pacemaker system were removed under cardiopulmonary bypass. Bacterial examination of arterial blood and vegetation attached to the leads showed septicemia caused by MRSA. After the operation, antibiotic therapy with vancomycin, arbekacin and minocycline was performed for several weeks. His postoperative course was uneventful without the recurrence of infection. In cases of pacemaker contamination, with septicemia, total removal of the pacemaker system and adequate antibiotic therapy are necessary. Jpn. J. Cardiovasc. Surg. $24: 347-350$ (1995)

植込み式ペースメーカーの感染は最近稀になっ てきたが，ときに感染性心内膜炎や敗血症などの 重篤な合併症を引き起こす危険性がある．今回著 者らは, メチシリン耐性黄色ブドウ球菌 (MRSA) によるペースメーカー感染から敗血症となった 1 例を経験したので報告する。

\section{症例}

症例：78 歳, 男性.

既往歴：76 歳時，心筋梗塞。

現病歴：1992 年 3 月, 洞機能不全症候群のため 近医で左鎖骨下よりVVIペースメーカーを挿入 した. 同年 12 月，リード断線のため同部位よりぺ

1994 年 6 月 21 日受付, 1994 年 12 月 12 日採用 群馬大学第 2 外科 $\bar{\top} 371$ 前橋市昭和町 3-39-15
ースメーカーリードを再挿入した. 1993 年 4 月, 左鎖骨下に膿瘍を形成し，切断留置したリード断 端およびジェネレーターが皮膚表面に露出した。 同年 5 月右鎖骨下より再度ペースメーカー入換え を行い，左銷骨下のジェネレーターを除去した。 その 2 日後より $39 \sim 40^{\circ} \mathrm{C}$ 発熱が連日みられた。 各種抗生剂や $\gamma^{-}$グロブリン製剤の投与で改善せ ず，リード感染による敗血症として当院に緊急入 院となった。

入院時現症：体温は $38.7^{\circ} \mathrm{C}$, 血圧は $116 / 80$ $\mathrm{mmHg}$, 脈拍は 80/分であった.悪寒戦慄および喘 鳴を認め, 左前胸部には直径 $10 \mathrm{~cm}$ 大の膿瘍があ った。心雑音はなかった。

入院時検査所見: 白血球は $7,800 / \mathrm{mm}^{3}$ と軽度 増加し, 血小板は 5.3 万 $/ \mathrm{mm}^{3}$ と減少していた。 


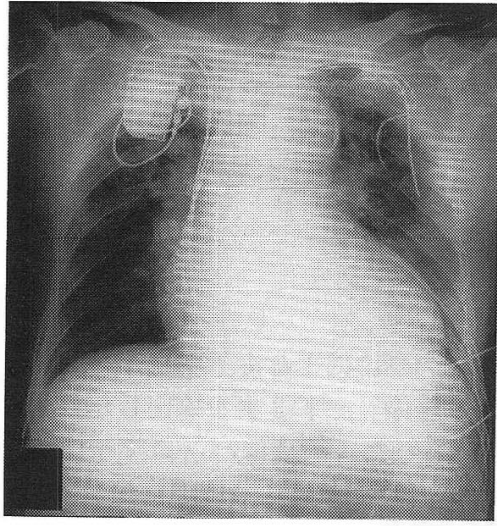

図 1 人院時胸部 $X$ 線写真

右鎖骨下にペースメーカーを，左鎖骨下に切断された 2 本の遺残り・ドを認める。

$\mathrm{CRP}$ は $56.2 \mathrm{mg} / \mathrm{dl}$ と著明に上昇していた。血清 の総ビリルビン值は $1.5 \mathrm{mg} / \mathrm{dl}, \mathrm{GOT} は 100 \mathrm{U} /$ $l$, GPT は $39 \mathrm{U} / l$, LDH は $764 \mathrm{U} / l$ と上昇し, $\mathrm{BUN}$, クレアチニンも $37 \mathrm{mg} / \mathrm{dl}, 1.7 \mathrm{mg} / \mathrm{dl}$ とお のおの上昇していた。DIC score は 6 点で, DIC 準 備状態と考えられた。胸部単純 X 線上, 心胸郭比 67\%と心拡大を認めた。右鎖骨下にはぺースメー カーが，左鎖骨下には切断された 2 本のリードが あった（図 1)。

以上よりペースメーカー感染による敗血症と診 断し，入院当日に緊急手術を施行した。

手術所見：初めに左前胸部感染創のデブリード メントを施行し，同部をサージカルドレープで密 閉した。次に胸骨正中切開で心囊を開き, 中等度 低体温, 体外循環下に blood cardioplegia を用い て心停止とした。右房を切開すると疗賣の付着し たリードが認められた。これらを右房内で離断後, スクリューの向きと反対に回転させ，心内の 3 本 のリードを順次摘出した。うち 2 本のリードには 疣贅が付着していた(図 2 )。三尖弁および右室内 には病贅の残存はなかった。右室内をバンコマイ シン加生理食塩水で十分に洗浄後, 右房を縫合閉 鎖した．永久ペースメーカーの心筋電極を右室前 面に装着後, 心囊および縦隔をバンコマイシン加 生理食塩水で洗浄して閉創した。大動脈遮断時間 は 38 分, 体外循環時間は 155 分であった。正中創 をドレープで被覆後，右前胸部よりジェネレータ ーとリードを，次いで左前胸部より 2 本のリード
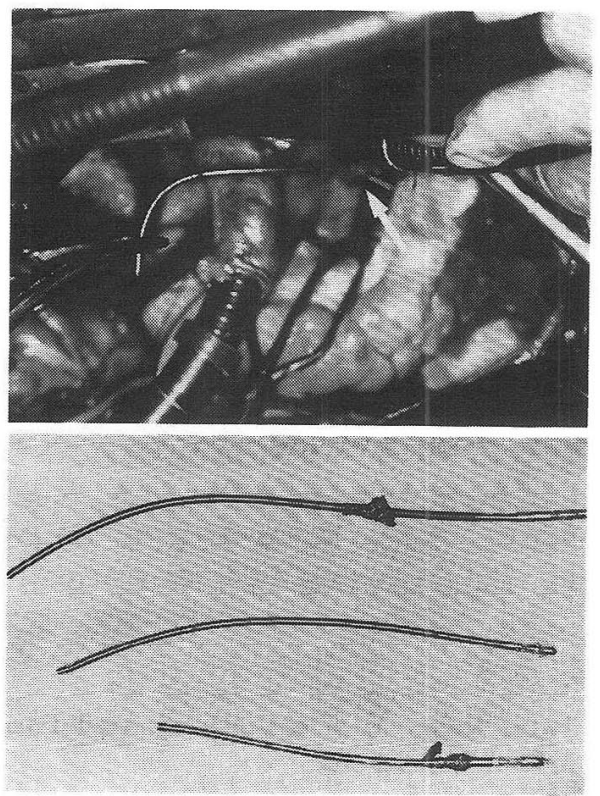

図 2 手術所見

（上)術中写真. 疣鳌がリードに付着している。(下)摘 出した 3 本のペースメーカーリード。

を摘出した。

術後経過：手術時に摘出したペースメーカーリ ード，疣贅，動脈血および左前胸部創部より細菌 培養でMRSA が検出された。術後の抗生物質は 感受性のあるアルベカシン，ミノサイクリン，バ ンコマイシン (VCM) などを投与した。動脈血培 養で術後もMRSA が検出されたが，第 8 病日以 降陰性となった。VCM は細菌培養陰性化後も 6 週間投与した。術後は心不全が持続したが徐々に 回復し，第 62 病日に内科転科となった（図 3 )。

\section{考察}

植込み式ペースメーカーの感染は 1 10\%にみ られる ${ }^{1}$ 。植込み後感染発症までの期間は，1か月 未満の早期のものから 10 年近く経って感染の徴 候を示すものまでさまざまだが2,3)，なかでも術後 2 年以内の発症が多い3)。

ペースメーカー感染の治療はリードを含めたシ ステム全体の摘出が原則である。しかし，最近の 心内膜電極はタインド型やフィン型などのアンカ 一機構を有しており抜去困難となることが多 く ${ }^{1,2)}$ ，開心術で直視下に抜去した例も少なくな 


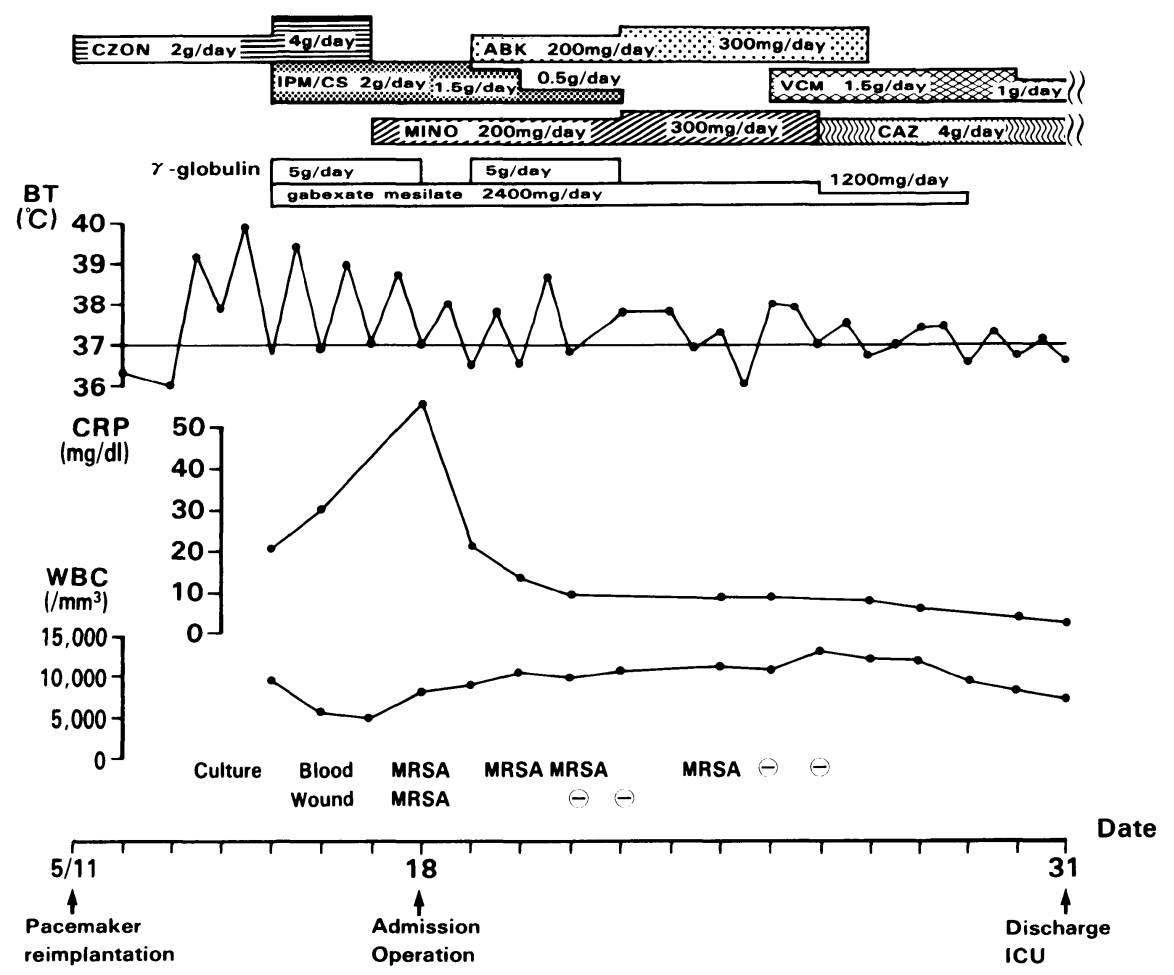

図 3 入院経過

CZON : Cefuzonam sodium, ABK: Arbekacin sulfate, IPM/CS : Imipenem/ Cilastatin sodium, VCM: Vancomycin hydrochloride, MINO: Minocycline hydrochloride, CAZ : Ceftazidime, BT : body temperature, CRP : C-reactive protein, WBC: white blood cell, MRSA: methicillin-resistant Staphylococcus aureus, ICU : intensive care unit.

(1). 非直視下の抜去法としては持続牽引・リード

リムーバルキット ${ }^{4)}$ ・バイオトームの使用5) 等があ る.しかし，植込み後長期間経過し三尖弁との癒 着やリード周囲に血栓がある場合は，抜去時に三 尖弁の損傷や肺塞栓などを起こす危険性があ る).

ペースメーカー感染による敗血症の発生頻度は $0.2 \sim 1.0 \%^{3,7,8)}$ だが, その死亡率は $25 \sim 40 \%^{7,8)}$ と 高く, MRSA 敗血症での救命例はほとんどない99. 自験例では人院時点で敗血症からの DIC 準備状 態にあり，緊急にペースメーカー摘出術を行った が，術後感染は発生しなかった。手術に際してリ ードを 2 期的に分けて摘出したこと，ドレープ使 用により感染部・非感染部を隔離したこと，さら にはバンコマイシン加生理食塩水による洗浄等が 術後感染防止に有用であったと考えている.また，
血管内への人工物留置を避けるため, 永久ペース メーカーの電極を右室前面に縫着した。開心術に よるリードの抜去は侵襲は大きいが，心内膜病変 の確認・感染病巣の完全摘除が可能であり, 本症 のごとき敗血症症例では第一選択にすべきであろ う.

抗生物質の投与は心内膜炎合併の有無と関係な く再発予防のため術後 $4 \sim 6$ 週間行うのが原則と されている ${ }^{10)}$. 自験例でも VCM を細菌培養陰性 化後 6 週間継続投与し，良好な結果を得た。

\section{結語}

MRSA によるペースメーカー感染から敗血症 を発生した 1 症例を報告した。開心術による直視 下のリード抜去とバンコマイシン等の抗生物質投 与により治癒しえた。 


\section{文献}

1）戸田省吾，中村昭光，岩本恒典ほか：開心術で摘 出した感染性ペースメーカーの 1 治験例. 胸部外 科 44:851-855, 1991 .

2）白川尚哉, 清水 健, 笹木秀幹ほか: 感染ペース メーカー症例の検討. 人工藏器 $20: 1013-1017$, 1991.

3）保坂浩希, 田中茂夫, 井村 肇ほか：ペースメー カー植込み術後の感染症. 心臓ペーシング 6 : 563-567, 1990.

4）野島武久, 森 渥視, 渡田正二ほか：感染性ペー スメーカーに対する電極抜去方法の検討. 胸部外 科 $46: 414-417,1993$.

5）松本秀一，木島幹博，池田精宏：感染を繰り返す ペースメーカー電極をバイオトームにて抜去し
えた 1 例. 心臓ペーシング $6: 323-325,1990$.

6）白井俊純，天野 純，杉本圭市ほか：人工心肺を 使用せずに摘出した抜去困難ぺースメーカーリ 一ドの 1 手術治験例. 循環器 $26: 511-516,1989$.

7）村瀬允也, 阿部稔雄, 石原智嘉：人工藏器と感染 ペースメーカー. 人工臟器 15：63-66, 1986.

8) Morgan, G., Ginks, W., Siddons, H., et al.: Septicemia in patients with an endocardial pacemaker. Am. J. Cardiol. 44 : 221-224, 1979.

9）野中健史, 池田晃治, 小石沢正ほか：ペースメー カー感染とその治療成績. 心臟ペーシング 8 : 218, 1992.

10）舟田 久：MRSA 感染症の臨床 (各科領域)一背 景因子, 予防対策と症候, 治療, 予後一MRSA 敗 血症. 日臨 50：163-168，1992。 